\title{
IDENTIFIKASI PENYEBAB BULLWHIP EFFECT PADA DISTRIBUSI PT ALFIAN JAYA DI
}

BALI

\author{
Gagas Gayuh Aji \\ Amak Mohamad Yaqoub \\ Departemen Manajemen Fakultas Ekonomi dan Bisnis Universitas Airlangga
}

\begin{abstract}
Abstrac
The purpose of the research is to identify the cause of the bullwhip effect and find solutions to overcome them. The object of research is demand and sales period of the year 2013 to 2014 on Alfian PT Jaya is. The phenomenon of the occurrence of changes in customer demand is relatively stable end of each day will be the order weekly or bi-weekly from retail company distribution center will receive orders more stable than demand faced by retail companies. Demand sole distributor will also stable, have an impact on the cost incurred by the company in storage. One way to analyze some of the causes of the bullwhip effect on the company is to analyze the factors that cause. Bullwhip value needs to be measured to determine the bullwhip effect can be done with the data aggregation method of Fransoo and Wouters.
\end{abstract}

Keywords: demand, sales, bullwhip effect

\section{PENDAHULUAN}

Pendekatan supply chain berkembang seiring dengan meningkatnya kebutuhan dunia usaha untuk menekan biaya secara menyeluruh. Salah satu permasalahan yang muncul adalah kelemahan pada aliran informasi dan koordinasi seringkali menimbulkan distorsi informasi yang salah satunya berupa terjadinya amplifikasi permintaan yang semakin besar pada upstream channel dibandingkan downstream channel yang dinamakan dengan fenomena bullwhip effect. Dalam kondisi ini maka fungsi dari sistem supply chain untuk menyediakan produk atau jasa yang tepat, pada tempat yang tepat, waktu yang tepat, dan kondisi yang diinginkan. Dimana teknologi telah mengubah logistik dari pengaturan persediaan dan transportasi menjadi suatu peningkatan nilai tambah dari barang dan jasa. Manajemen Rantai Pasokan (Supply Chain Management) merupakan bidang kajian yang terletak pada efisiensi dan efektifitas aliran barang, informasi, dan aliran vang yang terjadi secara simultan sehingga dapat menyatukan supply chain dengan pihak yang terlibat.

Inti dari supply chain adalah adanya sinkronisasi dan koordinasi ke arah hulu dan hilir. Hal ini mutlak dilakukan untuk menjaga efektifitas suatu rantai yang dibangun. Supply chain dapat diterapkan untuk mengintegrasikan manufaktur, pemasok, retailer, dan penjual 


\section{Gagas Gayuh Aji \\ Amak Mohamad Yaqoub}

secara efisien sehingga barang dapat diproduksi dan didistribusikan dengan jumlah yang tepat dan biaya keseluruhan yang minimum. Untuk menghasilkan supply chain yang efektif dan efisien perlu dibuat peta sistem logistik dan distribusi secara keseluruhan yang digunakan untuk melihat perilaku pergerakan aliran produk yang ditujukan untuk pendistribusian yang terjadi disetiap elemen. Untuk menciptakan pelayanan yang diinginkan, koordinasi antar pihak-pihak supply chain sangat diperlukan. Kurangnya koordinasi seringkali menimbulkan kesalahan informasi, yang salah satu akibatnya adalah variasi permintaan yang terjadi pada saluran supply chain. Variasi tersebut mengarah dari arah hilir ke hulu yang dinamakan fenomena bullwhip effect. Pada arah hilir yang berkaitan dengan retailer dan end user sedangkan arah hulu yang berkaitan langsung dengan manufacture.

Menurut Peter J Metrz (1998) dalam artikelnya yang berjudul "Demystifying Supply Chain Management" mengungkapkan bahwa dengan memanfaatkan konsep supply chain management perusahaan dapat memperoleh keuntungan seperti mereduksi persediaan barang jadi, out of stock incident berkurang, pendapatan perusahaan meningkat, cumulative cycle time berkurang, on time delivery naik, total cost share of revenue berkurang, serta inventory cost berkurang. Dan menurut Indrajit dan Djokopranoto (2002), keuntungan menerapkan supply chain management adalah mengurangi jumlah persediaan. Barang-barang persediaan yang merupakan aset perusahaan berkisar antara 30\%-40\% dari total aset perusahaan, sedangkan biaya persediaan berkisar antara $20 \%-40 \%$ dari nilai barang yang disimpan. Supply chain dapat menjamin kelancaran arus barang.

Sedangkan Bullwhip effect menurut Davids Simchi-levi (2000) dalam buku Designing and managing the supply chain, adalah sebagai berikut: "Peningkatan variability dari level bawah menuju level atas dan dalam suatu jaringan supply chain." Jadi dapat didefinisikan bahwa bullwhip effect sebagai peningkatan variabilitas permintaan yang terjadi pada setiap level supply chain sebagai akibat adanya distorsi informasi. Dalam situasi ini perusahaan tidak mempunyai informasi permintaan yang akurat (Lee etal,1997). Handfield dan Nichols (2002) menyatakan bahwa informasi yang tidak akurat atau informasi yang terdistorsi pada setiap level supply chain dari bawah ke atas dapat menimbulkan beberapa masalah penting, diantaranya adalah persediaan yang berlebihan, hilangnya pendapatan, turunnya tingkat kepuasan konsumen, pengiriman yang tidak efektif, kesalahan dalam penjadwalan produksi, serta penggunaan sumber daya yang tidak efisien. Panjangnya mata rantai pemasaran tersebut berdampak pada keputusan tentang jumlah pemesanan (order quantity), kebijakan persediaan (inventory policy), dan biaya (cost). Fenomena terjadinya perubahan permintaan pelanggan akhir yang relatif stabil dari hari ke hari akan menjadi order mingguan atau dua mingguan dari perusahaan ritel sehingga pusat distribusi akan menerima order yang lebih fluktuatif dibandingkan permintaan yang dihadapi oleh 116 


\section{Jurnal Manajemen Teori dan Terapan \\ Tahun 8. No. 2, Agustus 2015}

perusahaan ritel. Permintaan distributor tunggal juga akan berfluktuatif yang berdampak pada cost yang harus dikeluarkan oleh perusahaan dalam penyimpanan.

Salah satu cara untuk menganalisa beberapa faktor penyebab terjadinya bullwhip effect pada sebuah perusahaan adalah dengan menganalisis factor-faktor yang menyebabkan terjadinya. Tanya jawab dengan pihak ritel sangat diperlukan dalam penehuan imformasi permasalahan yang terjadi dan upaya yang akan diambil dalam rangka menyelesaian permasalahan perusahaan. Sebagaimana faktor yang dapat memicu terjadinya bullwhip effect pada supply chain, sehingga perlu dilakukan analisa seberapa jauh pengaruh terjadinya bullwhip effect dan faktor penyebab lainnya. Besarnya nilai bullwhip effect perlu diukur untuk mengetahui bullwhip effect yang dapat dilakukan dengan metode agregasi data Fransoo dan Wouters.

\section{Landasan Teori}

Bullwhip effect merupakan istilah yang digunakan dalam dunia inventory yang mendefinisikan bagaimana pergerakan demand dalam supply chain. Bullwhip yaitu cambuk, alat untuk mengendalikan sapi atau banteng. Konsepnya adalah suatu keadaan yang terjadi dalam supply chain, dimana permintaan dari customer mengalami perubahan, baik semakin banyak atau semakin sedikit, perubahan ini menyebabkan distorsi permintaan dari setiap stage supply chain. Distorsi tersebut menimbulkan efek bagi keseluruhan stage supply chain yaitu permintaan yang tidak akurat.

Bullwhip effect mengakibatkan banyak inefisiensi pada supply chain. Misalnya pabrik memproduksi dan mengirim lebih banyak dari yang sesungguhnya dibutuhkan akibat salah membaca signal permintaan dari pemain bagian hilir supply chain. Kegiatan dari pabrik dan pemasok lebih fluktuatif sehingga mereka sering lembur menghadapi pesanan yang berlebih atau menganggur karena distributor/ritel tidak memesan dalam waktu yang relatif panjang akibat mereka melakukan forward buying.

Pemakaian istilah "Bullwhip Effect" pertama kali diperkenalkan oleh perusahaan Procter\& Gamble (P\&G) pada permintaan popok bayi "Pampers" yang mengalami amplifikasi permintaan, dimana tingkat konsumsi "Pampers" berjalan konstan tetapi P\&G menemukan bahwa di distributor tingkat permintaan produk tersebut mengalami perubahan yang sangat cepat. Definisi Bullwhip effect menurut Christer Carlsson dan Robert Fuller (2001) adalah "Suatu fenomena dimana permintaan kepada supplier memiliki variansi yang besar daripada penjualan yang dilakukan kepadabuyer dan terjadi distorsi kepada level suppy chain yang lebih tinggi." Sedangkan Bullwhip effect menurut Davids Simchi-levi (2000), dalam buku Designing and managing the supply chain, adalah sebagai berikut: "Peningkatan variability dari level bawah menuju level atas dan dalam suatu network supplychain." Jadi dapat didefinisikan bahwa bullwhip effect sebagai peningkatan variabilitas permintaan yang terjadi pada setiap level supply chain sebagai akibat adanya 


\section{Gagas Gayuh Aji \\ Amak Mohamad Yaqoub}

distorsi informasi. Dalam situasi ini perusahaan tidak mempunyai informasi permintaan yang akurat (Lee et al,1997).

Handfield and Nichols (2002) menyatakan bahwa informasi yang tidak akurat atau informasi yang terdistorsi pada setiap level supply chain dari bawah ke atas dapat menimbulkan beberapa masalah penting, diantaranya :

1. Persediaan yang berlebihan

2. Hilangnya pendapatan

3. Turunnya tingkat kepuasan konsumen Customs

4. Pengiriman yang tidak efektif

5. Kesalahan dalam penjadwalan produksi

6. Penggunaan sumber daya yang tidak efisien

\section{Faktor Penyebab Bullwhip Effect}

Ada banyak hal yang bisa menyebabkan terjadinya bullwhip effect ini. Dalamhal ini menurut Lee et al (1997) mengidentifikasi 4 penyebab utama dari bullwhip effect yaitu:

a) Demand Forecast Updating

Demand yang jarang sekali stabil mengakibatkan peramalan permintaan yang kita buat juga jarang sekali akurat, sehingga terjadinya error pada forecast dimana perusahaan mengantisipasi dengan membuat safety stock. Namun jika ditarik dari produk jadi yang diserahkan ke customer sampai ke raw material yang ada dipabrik maka akan terlihat lonjakan demand yang sangat tajam. Pada periode dimana demand sedang melonjak maka seluruh partisipan pada chain akan meningkatkan inventorinya namun jika demand pada periode tertentu sedang turun maka partisipan harus menurunkan inventorinya. Akibat dari besarnya safety stock berpengaruh pada tidak efisiensinya produksi, dan juga mengakibatkan rendahnya utilization pada pendistribusian.

b) Order Batching

Pada saat inventory pada perusahaan sudah menurun, maka perusahaan biasanya tidak langsung memesan barang, ini dikarenakan perusahaan memesan berdasar order batching atau akumulasi permintaan sebelum memesan padasupplier. Biasanya order batching ada dua macam yaitu periodic ordering dan push ordering. Perusahaan biasanya memesan secara mingguan, dua mingguan atau bahkan bulanan. Jadi yang dihadapi oleh supplier ketika perusahaan memesansecara periodik adalah terjadinya tingkat permintaan yang tinggi untuk bulan inidisusun dengan kekosongan di bulan berikutnya. Pemesanan secara periodik ini mengakibatkan bullwhip effect. Salah satu masalah yang dihadapi untuk melakukan pemesanan secara frekuensi adalah masalah biaya transportasi, dimana terdapat perusahaan akan rugi jika memesan barang dengan muatan yang tidak penuh. 


\section{Jurnal Manajemen Teori dan Terapan \\ Tahun 8. No. 2, Agustus 2015}

c) Price Fluctuation

Manufaktur dan distributor biasanya membuat promosi secara periodikal, sehingga membuat pembeli melakukan permintaan menjadi lebih banyak dari yang sebenarnya dibutuhkan. Promosi semacam ini dapat membuat supply chain menjadi terancam, ini dikarenakan pembeli akan memesan lebih banyak dari yang dibutuhkan ketika sedang ada promosi dan ketika harga menjadi normal maka tidak ada pembelian karena customer masih memiliki stok barang. Ini membuat petapermintaan tidak menunjukkan pola yang sebenarnya. Dan variasi dari pembelianlebih besar dari variasi consumsion rate sehingga ini menimbulkan bullwhip effect.

d) Rationing and Shortage Gaming

Pada saat salah satu rantai dari supply chain ada yang melakukan "permainan" yang mengakibatkan pabrik tidak mengetahui permintaan pasar yang sebenarnya sehingga terjadi kekurangan atau kelebihan stok di pasaran yangmengakibatkan kekacauan di downstream, atau ada salah satu mata rantai yangmelakukan penimbunan barang agar terjadi kelangkaan dan menimbulkan kekacauan dimata rantai SCM, sehingga permintaan meningkat dari downstream. Ini juga mengakibatkan bullwhip effect.

\section{Pengukuran Bullwhip Effect Fransoo dan Wouters}

Menurut Fransoo dan Wouters (2000) ada beberapa a metode dalam mengukur bullwhip effect, yaitu:

1. Urutan agregasi data permintaan

2. Membuat daftar bermacam-macam penyebab adanya bullwhip effect

Sebuah supply chain terdiri dari beberapa echelon. Dimana echelon adalah satu tingkat pada pada supply chain yang ada di dalamnya terdiri dari beberapa outlet. Sebuah echelon bisa terdiri dari outlet pararel misalnya beberapa distributioncentre (DC) bersamasama membentuk echelon "DC", beberapa toko bersama-sama membentuk sebuah echelon "retail shop".

Bullwhip effect pada supply chain diukur dengan membagi koefisien variansi permintaan yang keluar ke echelon downstream (Cout) dengan koefisien variansi permintaan yang diterima oleh echelonupstream ( $\mathrm{C}_{\text {in }}$ ) dapat dilihat pada persamaan 1. Koefisien permintaan echelon tersebut dihitung dengan membagi standar deviasi permintaan dengan mean (rata-rata) permintaan (persamaan 2 dan 3). Pengukuran yang menghasilkan nilai lebih dari satu menunjukkan adanya peningkatan variabilitas permintaan (Fransoo dan Wouters, 2000). Dapat dikatakan pengukuran koefisien variansi permintaan 


\section{Gagas Gayuh Aji \\ Amak Mohamad Yaqoub}

yang masuk dengan keluar pada echelon yang menghasilkan nilai lebih dari satu, menunjukkan bahwa pada echelon tersebut terjadi bullwhip effect. Persamaan yang digunakan untuk mengukur indeks bullwhip effect adalah:

$$
\begin{array}{ll}
\omega & =\frac{C_{\text {out }}}{C_{\text {in }}} \\
& =\frac{\sigma\left(D_{\text {out }}(t, t+T)\right)}{\mu\left(D_{\text {out }}(t, t+T)\right)} \\
C_{\text {out }} & =\frac{\sigma\left(D_{\text {in }}(t, t+T)\right)}{\mu\left(D_{\text {in }}(t, t+T)\right)}
\end{array}
$$

Dimana:

$$
\begin{aligned}
& \omega \quad=\text { Koefisien variansi permintaan (bullwhip effect) } \\
& \text { Dout } \quad=\text { Permintaan yang kelvar menuju echelon downstream } \\
& \text { Din } \quad=\text { Permintaan yang datang dari echelon downstream } \\
& \text { Cout } \quad=\text { Koefisien variansi permintaan yang yang keluar ke echelon downstream } \\
& \text { C in } \quad=\text { Koefisien variansi permintaan yang masuk dari echelon downstream } \\
& \sigma\left(D_{\text {out }}(t, t+T)\right)=\text { Standar deviasi permintaan yang keluar dari sebuah chain } \\
& \mu\left(D_{\text {out }}(t, t+T)\right)=\text { Rata-rata permintaan yang keluar dari sebuah chain } \\
& \sigma\left(D_{\text {in }}(t, t+T)\right)=\text { Standar deviasi permintaan yang masuk ke sebuah chain } \\
& \mu\left(D_{\text {in }}(t, t+T)\right)=\text { Rata-rata permintaan yang masuk ke sebuah chain } \\
& (t, t+T)=\text { Interval waktu } \\
& D_{\text {in }}(t, t+T) \text { dan Dout }(t, t+T) \text { adalah permintaan yang masuk dan keluar selama interval }
\end{aligned}
$$
waktu tertentu. Selanjutnya $D_{\text {in }}(t, t+T)$ dan $D_{\text {out }}(t, t+T)$ akan ditulis sebagai $D_{\text {in }}$ danDout.

Dalam penelitiannya, Fransoo dan Wouters (2000) menjelaskan untuk mengidentifikasi bullwhip effect pada supply chain dapat dilakukan dengan mengukur bullwhip effect dengan agregasi data dan mengerti berbagai macam penyebab bullwhip effect.

\section{METODE PENELITIAN}

Pendekatan penelitian yang digunakan dalam menyusun penelitian ini adalah pendekatan kualitatif dengan metode studi lapangan deskriptif. Imforman yang dipergunakan dalam penelitian ini adalah Bagian Administrasi dan Umum PT Alfian Jaya, CV. Mega Raya, CV. Adi Jaya dan pemilik ritel 1, 2, 3, 4, 5. Metode pengumpulan data yang digunakan adalah sebagai berikut:

a) Wawancara melalui telepon dilakukan untuk memperoleh data primer

b) Dokumentasi untuk memperoleh data sekunder 
Unit Analisis yang digunakan adalah menghitung nilai bullwhip effect masing-masing retail, mengkaji faktor-faktor yang mempengaruhi terjadinya dan usulan perbaikan untuk menangani permasalahan bullwhip effect.

\section{HASIL ANALISIS DAN PEMBAHASAN}

\section{Penghitungan Nilai bullwhip effect pada PT Alfian Jaya}

Penghitungan berdasarkan 5 tipe sandal produk PT Alfian Jaya yaitu, sandal Woles, sandal Okley, sandal Converse, sandal Raffila dan sandal Kiddrock. Sandal Woles, pada tabel, akan disebut dengan notasi W. Begitu juga Okley yang dinotasikan $O$, Converse menjadi C, Raffila menjadi R dan juga Kiddrock menjadi K.

\section{Perhitungan indeks Bullwhip Effect Produk PT Alfian Jaya 2013}

\begin{tabular}{|c|r|r|r|r|r|r|l|}
\hline Type & Mean(s) & Mean & Std.dev (s) & Std.dev (d) & Cov.(s) & Cov.(d) & BE \\
\hline W & 86033 & 87025 & 3451,31 & 2347,97 & 0,04 & 0,03 & 1,49 \\
\hline O & 85951 & 86150 & 3000,23 & 2502,54 & 0,03 & 0,03 & 1,20 \\
\hline C & 85933 & 85900 & 2971,79 & 2520,46 & 0,03 & 0,03 & 1,18 \\
\hline R & 87029 & 87250 & 2631,84 & 2600,87 & 0,03 & 0,03 & 1,01 \\
\hline K & 85998 & 87283 & 2677,47 & 1443,38 & 0,03 & 0,02 & 1,88 \\
\hline Total & 795591 & 433608 & 6294,71 & 6432,09 & 0,01 & 0,01 & 0,53 \\
\hline
\end{tabular}

Sumber: Diolah dari data Perusahaan

Perhitungan indeks Bullwhip Effect Produk PT Alfian Jaya 2013

\begin{tabular}{|c|r|r|r|r|r|r|l|}
\hline Type & Mean(s) & Mean & Std.dev (s) & Std.dev (d) & Cov.(s) & Cov.(d) & BE \\
\hline W & 92501 & 91681 & 3721,08 & 2473,59 & 0,04 & 0,03 & 1,49 \\
\hline O & 92405 & 90759 & 3235,28 & 2636,48 & 0,04 & 0,03 & 1,21 \\
\hline C & 92378 & 90496 & 3194,67 & 2655,36 & 0,03 & 0,03 & 1,18 \\
\hline R & 93564 & 91918 & 2836,25 & 2740,03 & 0,03 & 0,03 & 1,02 \\
\hline K & 92448 & 91953 & 2878,28 & 1520,68 & 0,03 & 0,02 & 1,88 \\
\hline Total & 855317 & 456807 & 6803,77 & 6776,17 & 0,01 & 0,01 & 0,54 \\
\hline
\end{tabular}

Sumber: Diolah dari data Perusahaan

\section{Penghitungan Nilai bullwhip effect pada CV. Mega Raya}

Perhitungan Indeks Bullwhip Effect CV. Mega Raya 2013

\begin{tabular}{|c|l|l|l|l|l|l|l|}
\hline Type & Mean(s) & Mean (d) & Std.dev (s) & Std.dev (d) & Cov.(s) & Cov.(d) & BE \\
\hline W & 85784 & 86033 & 3523,3 & 3451,3 & 0,041 & 0,040 & 1,02 \\
\hline O & 85643 & 85951 & 3265,7 & 3000,2 & 0,038 & 0,035 & 1,09 \\
\hline C & 85694 & 85933 & 3093,0 & 2971,8 & 0,036 & 0,035 & 1,04 \\
\hline R & 87052 & 87029 & 2468,4 & 2631,8 & 0,028 & 0,030 & 0,94 \\
\hline K & 85296 & 85998 & 2987,0 & 2677,5 & 0,035 & 0,031 & 1,12 \\
\hline Total & 429468 & 430945 & 8080,1 & 5655,7 & 0,019 & 0,013 & 1,43 \\
\hline
\end{tabular}

Sumber: Diolah dari data Perusahaan 
Perhitungan Indeks Bullwhip Effect CV. Mega Raya 2014

\begin{tabular}{|c|r|r|r|r|r|r|r|}
\hline Type & Mean(s) & Mean (d) & Std.dev (s) & Std.dev (d) & Cov.(s) & Cov.(d) & \multicolumn{1}{l|l}{ BE } \\
\hline W & 92624 & 92501 & 3307,69 & 3721,08 & 0,04 & 0,04 & 0,89 \\
\hline O & 92821 & 92405 & 2416,75 & 3235,28 & 0,03 & 0,04 & 0,74 \\
\hline C & 92087 & 92378 & 2323,86 & 3194,67 & 0,03 & 0,03 & 0,73 \\
\hline R & 93987 & 93564 & 2080,96 & 2836,25 & 0,02 & 0,03 & 0,73 \\
\hline K & 91542 & 92448 & 2901,24 & 2878,28 & 0,03 & 0,03 & 1,02 \\
\hline
\end{tabular}

Sumber: Diolah dari data Perusahaan

Penghitungan Nilai bullwhip effect pada CV. Adi Jaya (Grosir) Bali

Perhitungan Indeks Bullwhip Effect CV. Adi Jaya 2013

\begin{tabular}{|c|r|r|r|r|r|r|r|}
\hline Type & Mean(s) & Mean (d) & Std.dev (s) & Std.dev (d) & Cov.(s) & Cov.(d) & \multicolumn{1}{l|}{ BE } \\
\hline W & 36517 & 36564 & 1176,92 & 1466,81 & 0,03 & 0,04 & 0,80 \\
\hline O & 36500 & 36515 & 1243,16 & 1264,11 & 0,03 & 0,03 & 0,98 \\
\hline C & 36658 & 36522 & 1217,64 & 1263,01 & 0,03 & 0,03 & 0,96 \\
\hline R & 36958 & 36987 & 817,38 & 1118,55 & 0,02 & 0,03 & 0,73 \\
\hline K & 36375 & 36549 & 1224,84 & 1137,93 & 0,03 & 0,03 & 1,08 \\
\hline Total & 183008 & 183137 & 2709,06 & 2665,48 & 0,01 & 0,01 & 1,02 \\
\hline
\end{tabular}

Sumber: Diolah dari data Perusahaan

Perhitungan Indeks Bullwhip Effect CV. Adi Jaya 2014

\begin{tabular}{|c|r|r|r|r|r|r|r|}
\hline Type & Mean(s) & Mean & Std.dev (s) & Std.dev (d) & Cov.(s) & Cov.(d) & BE \\
\hline W & 36500 & 36485 & 1566,70 & 1410,17 & 0,04 & 0,04 & 1,11 \\
\hline O & 36592 & 36706 & 1314,57 & 1137,42 & 0,04 & 0,03 & 1,16 \\
\hline C & 36130 & 36288 & 1354,15 & 1196,95 & 0,04 & 0,03 & 1,14 \\
\hline R & 37300 & 37197 & 570,49 & 907,95 & 0,02 & 0,02 & 0,63 \\
\hline K & 36747 & 36734 & 1250,58 & 1152,01 & 0,03 & 0,03 & 1,09 \\
\hline Total & 183268 & 183409 & 2160,91 & 2169,11 & 0,01 & 0,01 & 1,00 \\
\hline
\end{tabular}

Sumber: Diolah dari data Perusahaan

Penghitungan Nilai bullwhip effect pada Ritel

Dalam menghitung nilai bullwhip effect yang terjadi pada ritel-ritel yang ada dipulau Bali, maka dilakukan pengelompokkan data antara lain data pemesanan dan data penjualan sandal pada periode tahun 2013-2014.

Penghitungan berdasarkan 5 tipe sandal produk PT Alfian Jaya yaitu, sandal Woles, sandal Okley, sandal Converse, sandal Raffila dan sandal Kiddrock. Sandal Woles, pada tabel, akan disebut dengan notasi W. Begitu juga Okley yang dinotasikan O, Converse menjadi C, Raffila menjadi R dan juga Kiddrock menjadi K. 
Ritel 1

Nilai Bullwhip effect tahun 2013-2014 pada Ritel 1

\begin{tabular}{|l|l|l|l|l|l|l|l|l|}
\hline Tahun & Jenis & Mean(s) & Mean & Std.dev & Std.dev & Cov.(s) & Cov.(d) & BE \\
\hline & W & 130 & 134 & 28,50 & 28,27 & 0,22 & 0,21 & 1,04 \\
\hline & O & 133 & 136 & 22,34 & 25,41 & 0,17 & 0,19 & 0,90 \\
\cline { 2 - 9 } & C & 134 & 137 & 18,81 & 23,32 & 0,14 & 0,17 & 0,83 \\
\cline { 2 - 9 } & R & 145 & 145 & 26,81 & 22,48 & 0,18 & 0,15 & 1,19 \\
\hline \multirow{2}{*}{ Tahun } & K & 133 & 138 & 26,63 & 20,52 & 0,20 & 0,15 & 1,34 \\
\hline \multirow{3}{*}{} & Jenis & Mean(s) & Mean & Std.dev & Std.dev & Cov.(s) & Cov.(d) & BE \\
\hline & W & 124 & 129 & 28,05 & 25,90 & 0,23 & 0,20 & 1,13 \\
\hline & O & 127 & 133 & 24,29 & 23,24 & 0,19 & 0,18 & 1,09 \\
\hline \multirow{3}{*}{$\mathbf{2 0 1 4}$} & C & 124 & 127 & 25,44 & 20,90 & 0,21 & 0,16 & 1,25 \\
\hline & R & 132 & 137 & 24,64 & 23,60 & 0,19 & 0,17 & 1,09 \\
\hline & K & 128 & 136 & 23,81 & 22,40 & 0,19 & 0,16 & 1,13 \\
\hline
\end{tabular}

Sumber : Diolah dari data ritel 1

Ritel 2

Hasil Perhitungan nilai Bullwhip Effect periode tahun 2013-2014

\begin{tabular}{|c|c|c|c|c|c|c|c|c|}
\hline Tahun & Jenis & Mean(s) & Mean (d) & Std.dev & Std.dev & Cov.(s) & Cov.(d & BE \\
\hline \multirow[b]{5}{*}{2013} & W & 136 & 130 & 32,07 & 26,12 & 0,24 & 0,20 & 1,17 \\
\hline & 0 & 137 & 140 & 25,83 & 22,58 & 0,19 & 0,16 & 1,17 \\
\hline & C & 138 & 140 & 26,05 & 25,26 & 0,19 & 0,18 & 1,05 \\
\hline & $R$ & 146 & 144 & 22,95 & 22,20 & 0,16 & 0,15 & 1,02 \\
\hline & K & 139 & 129 & 23,42 & 24,52 & 0,17 & 0,19 & 0,89 \\
\hline Tahun & Jenis & Mean(s) & Mean (d) & Std.dev & Std.dev & Cov.(s) & Cov.ld & $\mathrm{BE}$ \\
\hline \multirow[b]{5}{*}{2014} & W & 135 & 141 & 32,16 & 26,92 & 0,24 & 0,19 & 1,24 \\
\hline & 0 & 139 & 145 & 26,18 & 24,10 & 0,19 & 0,17 & 1,13 \\
\hline & C & 139 & 150 & 26,04 & 25,58 & 0,19 & 0,17 & 1,10 \\
\hline & $R$ & 149 & 153 & 22,86 & 22,95 & 0,15 & 0,15 & 1,02 \\
\hline & K & 140 & 142 & 23,45 & 23,23 & 0,17 & 0,16 & 1,02 \\
\hline
\end{tabular}

Sumber: Diolah dari data ritel 2

Ritel 3

Hasil Perhitungan nilai Bullwhip Effect periode tahun 2013-2014

\begin{tabular}{|l|l|l|l|l|l|l|l|l|}
\hline Iahun & Jenis & Mean(s) & Mean & Std.dev & Std.dev & Cov.(s) & Cov.(d) & BE \\
\hline & W & 167 & 167 & 39,85 & 36,50 & 0,24 & 0,22 & 1,09 \\
\hline & O & 173 & 173 & 32,12 & 27,72 & 0,19 & 0,16 & 1,16 \\
\hline & C & 173 & 173 & 32,21 & 32,44 & 0,19 & 0,19 & 0,99 \\
\hline \multirow{3}{*}{2013} & R & 185 & 185 & 28,46 & 23,62 & 0,15 & 0,13 & 1,20 \\
\hline K & 173 & 173 & 29,00 & 31,28 & 0,17 & 0,18 & 0,93 \\
\hline \multirow{2}{*}{ Tahun } & Jenis & Mean(s) & Mean & Std.dev & Std.dev & Cov.(s) & Cov.(d) & BE \\
\hline & W & 132 & 134 & 29,94 & 24,55 & 0,23 & 0,18 & 1,24 \\
\hline & O & 138 & 141 & 25,85 & 27,03 & 0,19 & 0,19 & 0,98 \\
\hline & C & 130 & 130 & 24,77 & 22,84 & 0,19 & 0,18 & 1,09 \\
\hline & R & 143 & 141 & 26,90 & 24,72 & 0,19 & 0,18 & 1,07 \\
\hline
\end{tabular}




\begin{tabular}{|l|l|l|l|l|l|l|l|l|}
2014 & $\mathrm{~K}$ & 138 & 140 & 26,32 & 24,58 & 0,19 & 0,18 & 1,08
\end{tabular}

Sumber: Diolah dari data ritel 3

Ritel 4

Hasil Perhitungan nilai Bullwhip Effect periode tahun 2013-2014

\begin{tabular}{|c|c|c|c|c|c|c|c|c|}
\hline Tahun & Jenis & Mean(s) & Mean & Std.dev & Std.dev & Cov.(s) & Cov.(d) & BE \\
\hline \multirow[b]{5}{*}{2013} & W & 128 & 130 & 30,41 & 24,29 & 0,24 & 0,19 & 1,27 \\
\hline & 0 & 132 & 135 & 24,70 & 22,86 & 0,19 & 0,17 & 1,11 \\
\hline & C & 132 & 132 & 24,52 & 20,87 & 0,19 & 0,16 & 1,17 \\
\hline & $R$ & 141 & 139 & 21,68 & 18,94 & 0,15 & 0,14 & 1,13 \\
\hline & K & 133 & 134 & 22,06 & 20,35 & 0,17 & 0,15 & 1,10 \\
\hline Tahun & Jenis & Mean(s) & Mean & Std.dev & Std.dev & Cov.(s) & Cov.(d) & $\mathrm{BE}$ \\
\hline \multirow[b]{5}{*}{2014} & W & 125 & 127 & 28,51 & 23,05 & 0,23 & 0,18 & 1,26 \\
\hline & 0 & 131 & 134 & 24,46 & 18,60 & 0,19 & 0,14 & 1,35 \\
\hline & C & 123 & 122 & 23,59 & 17,18 & 0,19 & 0,14 & 1,37 \\
\hline & $\mathrm{R}$ & 135 & 134 & 25,54 & 19,11 & 0,19 & 0,14 & 1,32 \\
\hline & K & 131 & 133 & 24,79 & 16,96 & 0,19 & 0,13 & 1,48 \\
\hline
\end{tabular}

Sumber: diolah dari data ritel 4

Ritel 5

Hasil Perhitungan nilai Bullwhip Effect ritel 5 periode tahun 2013-2014

\begin{tabular}{|c|c|c|c|c|c|c|c|c|}
\hline Tahun & Jenis & Mean(s) & Mean & Std.dev & Std.dev & Cov.(s) & Cov.(d) & BE \\
\hline \multirow[b]{5}{*}{2013} & W & 127 & 130 & 30,19 & 24,54 & 0,24 & 0,19 & 1,26 \\
\hline & 0 & 131 & 130 & 24,47 & 20,89 & 0,19 & 0,16 & 1,17 \\
\hline & C & 131 & 131 & 24,21 & 18,32 & 0,19 & 0,14 & 1,32 \\
\hline & $R$ & 140 & 138 & 21,37 & 16,42 & 0,15 & 0,12 & 1,29 \\
\hline & K & 131 & 132 & 21,86 & 18,52 & 0,17 & 0,14 & 1,18 \\
\hline \multirow{6}{*}{2014} & Jenis & Mean(s) & Mean & Std.dev & Std.dev & Cov.(s) & Cov.(d) & $\mathrm{BE}$ \\
\hline & W & 124 & 124 & 28,21 & 24,04 & 0,23 & 0,19 & 1,17 \\
\hline & 0 & 129 & 128 & 24,21 & 20,39 & 0,19 & 0,16 & 1,18 \\
\hline & C & 121 & 122 & 23,29 & 18,01 & 0,19 & 0,15 & 1,30 \\
\hline & $R$ & 134 & 133 & 25,06 & 20,94 & 0,19 & 0,16 & 1,18 \\
\hline & K & 130 & 129 & 24,44 & 19,77 & 0,19 & 0,15 & 1,23 \\
\hline
\end{tabular}

Sumber: diolah dari data ritel 5

Dapat di simpulkan hasil dari perhitungan rata-rata per produk tiap ritel yaitu:

1. Besarnya nilai rata-rata bullwhip effect ritel 1 adalah sebesar 1,06 untuk tahun 2013 dan 1,138 di tahun 2014.

2. Nilai rata-rata Bullwhip Effect ritel 2 pada tahun 2013 adalah 1,06 sedangkan untuk nilai rata-rata Bullwhip Effect di tahun 2014 adalah sebesar 1,102,

3. Nilai rata-rata Bullwhip Effect ritel 3 pada tahun 2013 adalah 1,074 sedangkan untuk nilai rata-rata Bullwhip Effect di tahun 2014 adalah sebesar 1,092,

4. Nilai rata-rata Bullwhip Effect ritel 4 pada tahun 2013 adalah 1,156 sedangkan untuk nilai rata-rata Bullwhip Effect di tahun 2014 adalah sebesar 1,356, 


\section{Jurnal Manajemen Teori dan Terapan \\ Tahun 8. No. 2, Agustus 2015}

Nilai rata-rata Bullwhip Effect ritel 5 pada tahun 2013 adalah 1,244 sedangkan untuk nilai rata-rata Bullwhip Effect di tahun 2014 adalah sebesar 1,212 dan nilai rata-rata Bullwhip Effect pada tahun 2013 tertringgi dimiliki oleh ritel 5 sebesar 1,213 sedangkan Bullwhip Effect tertinggi pada tahun 2014 adalah sebesar 1.356 dimiliki oleh ritel 4 .

Bullwhip Effect yang terjadi pada masing-masing ritel disebabkan oleh faktor - faktor measurement, environment dan manpower. Sebagai berikut:

a) Environment

Fluktuasi permintaan pada hari libur untuk hari Raya dan hari liburan sekolah sehingga menyebabkan jalan menuju pulau Bali macet, baik darat maupun penyeberangan Ketapang Gilimanuk. terjadi karena adanya permintaan yang fluktuatif. Pada periode liburan dan hari raya umat beragama demand akan meningkat yang berpotensi pada kondisi dimana kapasitas permintaan ritel tidak dapat memenuhi tingginya permintaan pasar. Begitu juga pada akhir tahun dan awal tahun ketika terdapat event tahun baru penjualan sandal akan meningkat. Hal tersebut tentu saja dapat menyebabkan terjadinya bullwhip effect pada ritel. Penjualan sandal biasanya menurun pada hari-hari biasa. Perubahan permintaan terjadi ketika pihak ritel melakukan pembatalan order dan melakukan penambahan atau pengurangan order pada sandal. waktu yang berhubungan dengan keterlambatan. Keterlambatan sering terjadi sebagai akibat dari kesalahan yang dilakukan oleh manusia (tenaga kerja), transportasi (sarana dan prasarana) serta keadaan alam. Faktor eksternal atau faktor alam yang menghambat adalah ekspedisi sandal dari Surabaya ke Denpasar Bali menggunakan jalur darat. Menggunakan truk-truk ekspedisi yang melewati penyeberangan ketapang Gili Manuk. Seringnya macet akibat penyeberangan ini dapat menimbulkan keterlambatan barang sampai ke Adi Jaya selaku whole seller. Sehingga mempengaruhi keterlambatan pemenuhan pesanan ke masing-masing ritel

b) Measurement

Ritel tidak memiliki metode pengukuran peramalan permintaan dan pejualan masa depan dan Ritel hanya mengandalkan salesman yang datang menawarkan barang, sehingga mengakibatkan ada saat tertentu terjadi penumpukan stock dan kadang terjadi kekurangan stock. Pada bulan-bulan tertentu seperti menjelang liburan sekolah, hari raya Idul Fitri dan Natal dimana banyak konsumen membeli sandal daripada periode lainnya, penimbunan stock akan dilakukan oleh pihak ritel. Pihak ritel melakukan pemesanan sandal diluar kapasitas ruang penyimpanan. Ini sangat mungkin terjadi Short supply, yang artinya perintaan melebihi supply dari manufaktur ke ritel. Mengingat bahwa kapasitas permintaan sandal terbatas. Pihak ritel juga tidak memiliki metode peramalan permintaan yang akurat. Dalam hal ini masing-masing ritel tidak menggunakan metode khsusus dalam meramalkan permintaan barang kepada Adi Jaya, mereka hanya menggunakan perkiraan atas penjualan yang terjadi pada periode sebelumnya. Hal ini yang akhirnya menyebabkan 


\section{Gagas Gayuh Aji \\ Amak Mohamad Yaqoub}

penumpukan sisa produk, akan tetapi mereka memiliki solusi tersendiri yang menurut mereka efektif dalam mengatasi penumpukan. Akhirnya ritel tidak memberikan informasi demand yang sebenarnya sehingga terjadi demand yang tidak stabil, baik dalam hal jumlah permintaan (demand yang dilebihkan) atau information sharing. Sehingga ritel dapat melakukan pemesanan dalam jumlah yang banyak melebihi kebutuhannya sebagai antisipasi atas terjadinya peningkatan permintaan di periode mendatang.

c) Manpower

Bagian pengiriman kurang jeli dalam mengestimasi kondisi lalu lintas menuju pulau Bali sehingga Sering terjadi keterlambatan barang masuk ke ritel. Salesman kurang agresif dalam mengecek stock barang di ritel sehingga menyebabkan sering terjadi kekurangan stock barang di ritel. Kesalahan yang disebabkan oleh sumber daya manusia yaitu karyawan yang harusnya dapat melakukan sortir atas sandal cacat yang disebabkan oleh salah jahit, jahitan lepas, dan sebagainya yang dapat menyebabkan penurunan volume penjualan. Kapasitas pesan ritel yang seharusnya membentuk kuota sandal maksimal menjadi tidak maksimal karena adanya kesalahan tersebut. Tidak dapat dipungkiri sandal cacat menyebabkan kerugian pada ritel. Selain itu di pihak whole saller keagresifan dari sales menjadi ujung tombak keberhasilan distribusi ke ritel. Selanjutnya adalah masalah transportation, yaitu adanya keterlambatan pengiriman dari distributor sampai ke Ritel di Bali. Adanya keterlambatan ini disebabkan beberapa faktor, baik faktor alam maupun faktor dari dalam kondisi Distributor dan Wholesaller itu sendiri.

Hasil tersebut sesuai dengan pendapat dari Lee et al (1997:95) terdapat lima hal yang dapat menyebabkan terjadinya bullwhip effect pada supply chain satu ritel, antara lain adalah Demand forecasting, rationing, batch ordering, fluktuasi harga, shortage gaming. Kelima faktor tersebut diyakini dapat menyebabkan terjadinya bullwhip effect pada sebuah ritel manufaktur. Penyebab bullwhip effect yang pertama adalah fluktuasi harga. Pada penyebab ini tidak menjadi permasalahan bullwhip effect pada ritel, mengingat bahwa sandal sandal adalah kebutuhan pokok manusia. Sehingga perubahan harga yang tidak terlalu besar tidak menyebabkan perubahan permintaan sandal oleh pelanggan.

Pada peramalan permintaan atau demand forecasting ini menjadi salah satu penyebab terjadinya bullwhip effect pada aliran supply chain ritel. Peramalan permintaan dilakukan karena ritel tidak bisa mengetahui secara pasti berapa jumlah sandal yang akan diminta pada satu periode tertentu. Pada periode liburan dan hari raya umat beragama demand akan meningkat yang berpotensi pada kondisi dimana kapasitas permintaan ritel tidak dapat memenuhi tingginya permintaan pasar. Permintaan sandal sandal yang fluktuatif ini juga disebabkan oleh ritel yang tidak memiliki metode forecast yang tidak akurat sehingga ritel sering melakukan perubahan order sandal sandal. 
Hasil penelitian menunjukkan bahwa yang menjadi penyebab terjadinya bullwip effect pada ritel adalah masalah demand frocasting, order batching dan lead time. Rationing dan fluktuasi harga tidak terjadi di perusahaan karena pihak disttibutor tidak pernah memberikan discount pada pada ritel. Karena barang yang dijual adalah barang dengan harga dengan murah dan penjualan yang dilakukan berdasarkan pada pesanan yang dilakukan oleh pihak distributor.

\section{Analisa Menggunakan Diagram Fishbone Ishikawa}

Identifikasi penyebab terjadinya bullwhip effect, digambarkan dalam diagram fishbone. Penggunaan diagram fishbone ini bertujuan untuk mempermudah mengidentifikasi banyaknya penyebab yang mungkin dari sebuah efek atau permasalahan dengan mengurutkan permasalahan-permasalahan dalam satu kategori. Diagram fishbone merupakan suatu alat visual untuk mengidentifikasi, mengeksplorasi, dan secara grafik menggambarkan secara detail semua penyebab yang berhubungan dengan suatu permasalahan. Menurut Scarvada (2004), konsep dasar dari diagram fishbone adalah permasalahan mendasar diletakkan pada bagian kanan dari diagram atau pada bagian kepala dari kerangka tulang ikannya. Penyebab permasalahan digambarkan pada sirip dan durinya. Diagram sebab akibat atau dikenal dengan fishbone diagram dapat dilihat pada gambar 6 berikut ini:

\section{Gambar 2}

\section{Penyebab Bullwhip Effect dalam Fishbone}

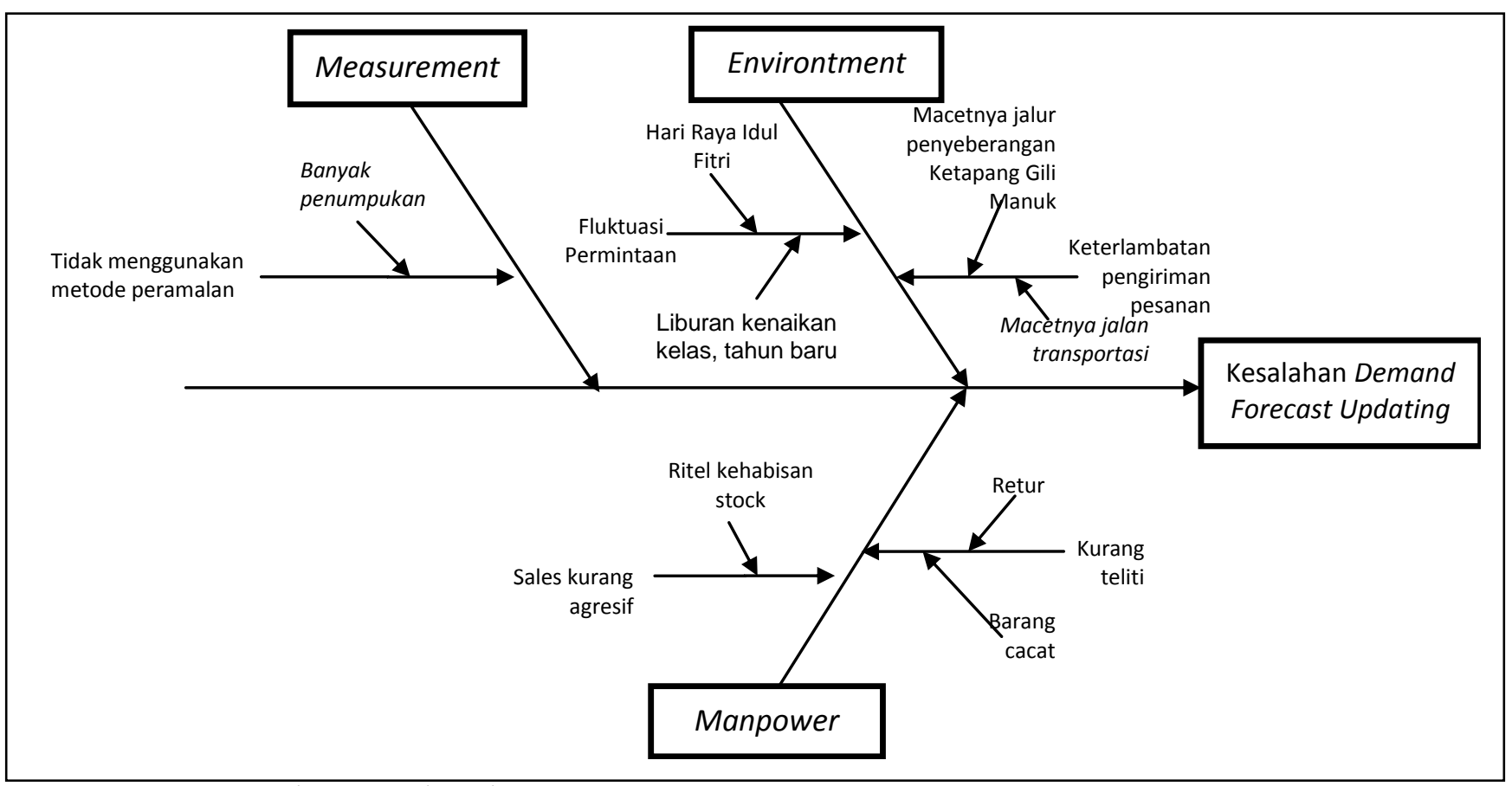

Sumber: data diolah dari hasil wawancara

\section{d) Usulan perbaikan}




\section{Gagas Gayuh Aji \\ Amak Mohamad Yaqoub}

Usulan perbaikan diberikan untuk mengurangi bullwhip effect untuk setiap faktorfaktor yang dapat dikendalikan ritel. Penyebab bullwhip effect seperti hari raya merupakan faktor penyebab di luar kendali ritel. adapun usulan perbaikan yang dapat dilakukan dengan cara-cara sebagai berikut:

1. Distributor pusat yaitu CV. Mega Raya sebaiknya menjadwal ulang tanggal pengiriman. Hal ini dapat dilakukan pada waktu-waktu tertentu dimana jadwal macet di penyeberangan Ketapang Gilimanuk sedang terjadi. Juga rute jalan darat yang sering macet berdasarkan periode-periode tertentu.

2. Perusahaan menggunakan metode pencatatan persediaan yang akurat, karena selama ini toko hanya memperkirakan saja jumlah pesanan. Dan memanfaatkan produks sisa sebelumnya tinggal di tambah prosentase saja.

3. Perusahaan memiliki tenaga khusus bagian administrasi yang mencatat semua berkaitan dengan proses pesanan dan penjualan sandal dengan metode komputerisasi, yang selama ini hanya menggunakan catatan manual. Karena dengan menggunakan metode komputerisasi maka secara otomatis dapat terlihat jumlah pesanan yang dibutuhkan serta jumlah sisa stok yang terdapat di gudang.

4. Membuat jadwal waktu pemesanan barang, hal ini dimaksudkan untuk menjadi terjadinya keterlambatan pengiriman barang.

\section{SIMPULAN DAN SARAN}

\section{A. Kesimpulan}

Bullwhip Effect yang terjadi pada masing-masing ritel disebabkan oleh faktor - faktor measurement, environment dan manpower. Sebagai berikut:

1. Environment: Fluktuasi permintaan pada hari libur untuk hari Raya dan hari liburan sekolah

2. Measurement.

a. Ritel tidak memiliki metode pengukuran peramalan permintaan dan pejualan masa depan

b. Ritel hanya mengandalkan salesman yang datang menawarkan barang.

3. Manpower

a. Bagian pengiriman kurang jeli dalam mengestimasi kondisi lalu lintas menuju pulau Bali.

b. Salesman kurang agresif dalam mengecek stock barang di ritel

\section{A. Saran}

Pada penelitian selanjutnya dalam mengukur indeks bullwhip effect dapat menggunakan metode kuantitatif dengan melakukan semua pengukuran agregasi data pada setiap rantai. Analisa penyebab terjadinya bullwhip effect dapat di lakukan dengan menganalisa sistem persediaan yang digunakan oleh perusahaan tersebut. 


\section{Jurnal Manajemen Teori dan Terapan \\ Tahun 8. No. 2, Agustus 2015}

\section{Daftar Referensi}

Ahyari, Agus. (1987). Pengendalian Sistem Produksi Buku 1 dan 2. BPEF. Yogyakarta.

Alifen, R. S, Setiawan, R. S, Sunarto, A. (2000). Analisa "What If" Sebagai Metode Antisipasi Keterlambatan Durasi Proyek. Dimensi Teknik Sipil, Vol. 2 No. 1, Maret.

Aji, Gagas Gayuh dan Amak Mohamad Yaqoub, 2015. Identifikasi Penyebab Bullwhip Effect Produk PT. ALFIAN JAYA Pada Jaringan Distribusi di Ritel BALI, Program Studi S1 Manajemen Fakultas Ekonomi dan Bisnis Universitas Airlangga, 143.

Andi, Susandi, Wijaya. H. (2003). Representing Factors Influencing TimePerformance Of ShopHouse Contructions In Surabaya, Dimensi Teknik Sipil, Vol. 5 No. 2, September.

Assaf, A. (1995). Causes of Delay in Large Building Construction Projects, Journal of Management in Engineering. Assauri, Sofjan. (2008). Manajemen Produksi dan Operasi, Jakarta : Lembaga Penerbit Fakultas Ekonomi Universitas Indonesia.

Blaxter, L., Hughes, C., \& Tight, M. (2001). How To Research. Maidenhead: Open University Press.

Chase, Aquilano, dan Jacobs, 2001, Operation Management : For Competitive Advantage, Int. Editions, 9th edition, The Mc Graw-Hill/Irwin Series.

Chen, I.J. and Paulraj, A. (2004), "Understanding supply chain management: critical research and a theoretical framework", International Journal of Production Research, Vol. 42 No. 1, pp. 131-63.

Chopra, Sunil., Meindl, Peter., (2001), Supply Chain Management : Theory and Implementation, Mc Graw-Hill, New York-USA.

Dipohusodo, Istimawan. (1996). Manajemen Proyek dan Konstruksi jilid 1 dan 2. Kanisius. Yogyakarta.

Donal S. Barie, (1984), Delay Caused by Owner on His Agent. Mc Graw-Hill. New York-USA.

Fawcett, S.E. and Magnan, G.M. (2002), "The rhetoric and reality of supply chain integration", International Journal of Physical Distribution \& Logistics Management, Vol. 32 No. 5 , pp. 339-351.

Fawcett, S.E., Magnan, G.M. and Mccarter, M.W. (2008), "Benefits, barriers, and bridges to effective supply chain management", Supply Chain Management: An International Journal, Vol. 13, pp. 35-48.

Indrajit, Richardus E., Djokopranoto, Richardus., (2003), Konsep Manajemen Supply Chain : Cara Baru Memandang Mata Rantai Pernyediaan Barang, Cetakan Ketiga, PT. Gramedia Widiasaranan Indonbesia, Jakarta.

Keely L. Croxton. (2003). The Order Fulfillment Process. International Journal of Logistics. Vol. 14 Iss: 1, Pp. 19-32. 


\section{Gagas Gayuh Aji \\ Amak Mohamad Yaqoub}

King, L, Peter. (2011). Crack the Code, Understanding Safety Stock \& Mastering Its Equation. CSCP, APICS Magazine.

Lambert, D.M., Stock, J.R., (2001), Strategic Logistic Management, Fourth Edition, Mc GrawHill, New York-USA.

Lambert, D.M., Cooper, M.C. and Pagh, J.D. (1998), Supply chain management: implementation issues and research opportunities, International Journal of Logistics Management, Vol. 9 No. 2, pp. 1-20.

Lambert, D.M., Garci'a-Dastugue, S.J. and Croxton, K.L. (2008), "The role of logistics managers in the crossfunctional implementation of supply chain management", Journal of Business Logistics, Vol. 29 No. 1, pp. 113-132.

Power, D. (2005), "Supply chain management integration and implementation: a literature review", Supply Chain Management: An International Journal, Vol. 10, pp. 252-263.

Proboyo, B. (1999). Keterlambatan Waktu Pelaksanaan Proyek : Klasifikasi Dan Peringkat Dari Penyebab-Penyebabnya, Dimensi Teknik Sipil, Vol. 1 No. 2, September.

Scarvada, A.J., Tatiana Bouzdine-Chameeva, Susan Meyer Goldstein, Julie M. Hays, Arthur V. Hill. 2004. A Review of the Causal Mapping Practice and Research Literature. Second World Conference on POM and 15th Annual POM Conference, Cancun, Mexico, April 30 - May 3, 2004.

Schroeder, Roger, G, 2000, Operations Management, Internal ed, Mc Graw-Hill Companies. Inc.

Serat, Olivier. (2009). The Five Whys Technique: Asian Development Bank.

Silalahi, Ulber. (2006). Metode Penelitian Sosial. Bandung: Unpar Press.

Svensson, G., 2000. A conceptual framework for the analysis of vulnerability in supply chains: International Journal of Physical Distribution \& Logistics Management, 30 (9), 731-750.

Tague, N. R. (2005). The quality toolbox. (2th ed.). Milwaukee, Wisconsin: ASQ Quality Press.

Utami, Issa Dyah. (2005). Pendekatan Leagile Supply Chain Guna Mereduksi Total Cycle Time dari Order Fulfillment Process (Studi Kasus di PT. Wala Plastik Lamongan): Fakultas Teknik Industri Institut Sepuluh Nopember Surabaya. 